\title{
New Conditions of Saturation of Aqueous Solutions for the Modeling of Regions of Solid Phases
}

\author{
R.A. Yusupov ${ }^{1, *}$, Z.T. Dinh ${ }^{2}$ and S.A. Bakhteev ${ }^{2}$ \\ ${ }^{1}$ Kazan National Research Technological University, 420012, Kazan, Ulyanov-Lenin, 57, Apt. 40, Russia \\ ${ }^{2}$ Kazan National Research Technological University, 420005, Kazan, G. KAYBITSKY, 12, Apt. 117, Russia
}

\begin{abstract}
In modeling the regions of precipitation and formation of thin films, we used four conditions: 1 . The rule of solubility product; 2 . The rule of molecular solubility; 3 . The rule of solubility by intermediate; 4 . Condition of precipitate of priority. This technique was used to build mathematical models of equilibriums from the $\mathrm{pH}$ of solution, concentration of reactants, and temperature. Mathematical models were also developed on the basis of experimental data obtained by potentiometry, residual concentration, thermogravimetry, etc. This model considers fluctuations of the $\mathrm{pH}$ of solution and predicts the chemical composition of compounds. It has been demonstrated that in synthesizing target compounds, the possibility of processes of fluctuations must be taken into account. A systemic mathematical model has been designed to optimize the synthesis of thin films and target compounds.
\end{abstract}

Keywords: Mathematical modelling of equilibriums; conditions of saturation of aqueous solutions; the thin films of the lead sulfide.

\section{INTRODUCTION}

Currently, available software products presented in Table 1, are capable of solving the problems specified in the table. It is often necessary to also perform the following tasks:

1. Modeling of regions of existence of various precipitate species in a single system;

2. Modeling of regions of formation of thin films on substrates;

3. Integration of the memory effect of solution, accounting for the presence of slowly-forming compounds;

4. Representation of significant growth of mole fractions of polynuclear and heteronuclear compounds with increasing concentration of standard reagents;

5. Determination of the formation of a large number of compounds in significant mole fractions in the material balance equation of a system (currently, the number of compounds must be about 100; slightly less than half of them are in the form of precipitates);

6. Accounting for the hydrolysis of these compounds;

7. Prediction of fluctuations in the system's parameters. It is recommended to solve all the

*Address correspondence to this author at the Kazan National Research Technological University, 420012, Kazan, Ulyanov-Lenin, 57, Apt. 40, Russia; Tel: 8-917-390-31-87; E-mail: yusupovraf@yandex.ru problems listed above, as well as those in Table 1 , using only one program. In the end, we have to develop a software product for solving all the problems above.

The most fundamental problem in modeling the regions of formation of precipitates (solid phase); and especially, different precipitate species in one chemical system, is the inadequacy of using only the rule of solubility product. For example, using this rule, it is impossible to model the regions of sequential formation of metal oxides with identical stoichiometric components on the $\mathrm{pH}$ scale. Below are other problems that arise:

1. In the formation of different precipitate species in a single system with overlapping regions of existence, the problem of choosing the precipitate of priority arises;

2. Upon mixing the solutions of reagents, there arises a kinetic state of formation of precipitates. This kinetic state can be significantly determined by the equilibrium processes of these reagents before their mixing; an observation in the synthesis of thin films of chalcogenides and metal oxides in aqueous solutions;

3. Insufficient number of equilibrium constants presented in reference literature, and large deviations in the values of these constants.

The aim of this work is to overcome the problems mentioned above; for which the following are required:

1. Obtaining experimental data through the application of different research methods and a 
wide range of concentration values of reactants and other parameters.

2. Establishment of the number of particles which determine the system's properties. In the presence of several precipitate species within the same system, the number of particles is not less than double the number of the precipitates. Upon increasing the concentration of reactants, the number of particles increases sharply due to the formation of polynuclear, heteroligand, and other compounds, and the formation of new precipitates. The number of particles in the system can be determined reliably only in the presence of a systemic mathematical model that takes into account all the experimental data.
3. Description of regions of formation of different types of precipitates, which are formed in a single system; by applying the rules of molecular solubility, solubility by intermediate, choosing the precipitate of priority; in addition to the rule of solubility product [1, 2].

4. Drawing up logistics of calculations of equilibrium constants; based on theoretical knowledge [3-5], experimental priori and data [6, 7].

5. Accounting for the effects of secondary factors such as ionic strength [5] and viscosity of solution, kinetic factors in determining the true equilibrium in solution, and the occurrence of

Table 1: Capabilities of Software Packages for the Equilibrium Calculation. Methods: Potentiometric Titration (PT), Residual Concentration (RC)

\begin{tabular}{|c|c|c|c|c|c|}
\hline Capabilities & MINEQL + 3.0 & MINEQL+ 4.6 & $\begin{array}{l}\text { CHEPP (Chemical } \\
\text { Equilibrium } \\
\text { Program Package) }\end{array}$ & $\begin{array}{c}\text { CALPHAD } \\
\text { (Calculation of } \\
\text { Phase Diagram) }\end{array}$ & $E Q-Y$ \\
\hline \multirow{4}{*}{$\begin{array}{c}\text { Modeling of regions of existence of } \\
\text { precipitates, applying the following } \\
\text { conditions: } \\
\text { Solubility product; } \\
\text { Molecular solubility; } \\
\text { Solubility by intermediate; } \\
\text { Selection of precipitate of priority }\end{array}$} & + & + & + & + & + \\
\hline & - & - & - & - & + \\
\hline & - & - & - & - & + \\
\hline & - & - & - & - & + \\
\hline $\begin{array}{l}\text { Modeling of regions of various } \\
\text { precipitates and thin films }\end{array}$ & - & - & - & - & + \\
\hline \multicolumn{6}{|l|}{$\begin{array}{l}\text { Calculation of constants from } \\
\text { experimental data: }\end{array}$} \\
\hline 1. automatic mode & + & + & + & + & + \\
\hline 2. manual mode & - & - & - & - & + \\
\hline Task dimensions & $?$ & $?$ & $?$ & 100 & $\begin{array}{l}\text { 100/7 (manual } \\
\text { \& automatic } \\
\text { modes) }\end{array}$ \\
\hline $\begin{array}{c}\text { Modeling of metrological properties of } \\
\text { constants }\end{array}$ & - & - & - & - & + \\
\hline Presence of Database & + & + & $?$ & + & + \\
\hline Objects & $\begin{array}{l}\text { Aqueous } \\
\text { solutions }\end{array}$ & $\begin{array}{l}\text { Gases, } \\
\text { liquids, } \\
\text { solids }\end{array}$ & $\begin{array}{c}\text { Plasma } \\
\text { (for fuel } \\
\text { combustion } \\
\text { in air) }\end{array}$ & $\begin{array}{l}\text { Gases, } \\
\text { liquids, } \\
\text { solids }\end{array}$ & $\begin{array}{l}\text { Aqueous } \\
\text { solutions }\end{array}$ \\
\hline $\begin{array}{l}\text { Computation of } \mathrm{PT} \text { and } \mathrm{RC} \text { curves, } \\
\text { with respect to precipitation }\end{array}$ & + & + & $?$ & $?$ & $\begin{array}{l}+ \\
+\end{array}$ \\
\hline Simulation of $\mathrm{pH}$ fluctuations & - & - & - & - & + \\
\hline $\begin{array}{l}\text { Simulation of hydrolysis of reagents with } \\
\text { respect to all particles in the material } \\
\text { balance equation }\end{array}$ & - & - & - & - & + \\
\hline $\begin{array}{c}\text { Calculation of the ionic strength of } \\
\text { solution }\end{array}$ & - & - & - & + & + \\
\hline $\begin{array}{l}\text { Calculation of the necessary number of } \\
\text { particles in the material balance equation }\end{array}$ & - & $?$ & $?$ & $?$ & + \\
\hline
\end{tabular}


oxidation-reduction reactions, as well as other processes.

\section{THEORY}

An essential requirement in the modeling of regions of formation of solid phases in the form of precipitates or thin films in the [metal ion- $\mathrm{H}_{2} \mathrm{O}-\mathrm{OH}^{-}$] reagent systems, is the computation of equilibriums in homogeneous and heterogeneous systems [6 - 7]. As an example, Figure 1 shows a graph (schematic diagram) of the major equilibriums in the $\left[\mathrm{Pb}(\mathrm{II})-\mathrm{H}_{2} \mathrm{O}-\right.$ $\mathrm{OH}^{-}$, thiourea (TU)] system. About 40 compounds are represented on the scheme; and slightly less than half of them are in the form of precipitates. Expressions for the equilibrium constants are presented in Table 2. Modeling of regions of compound formation, with respect to $\mathrm{pH}$ and concentrations of the reactants, becomes very difficult when the computation of

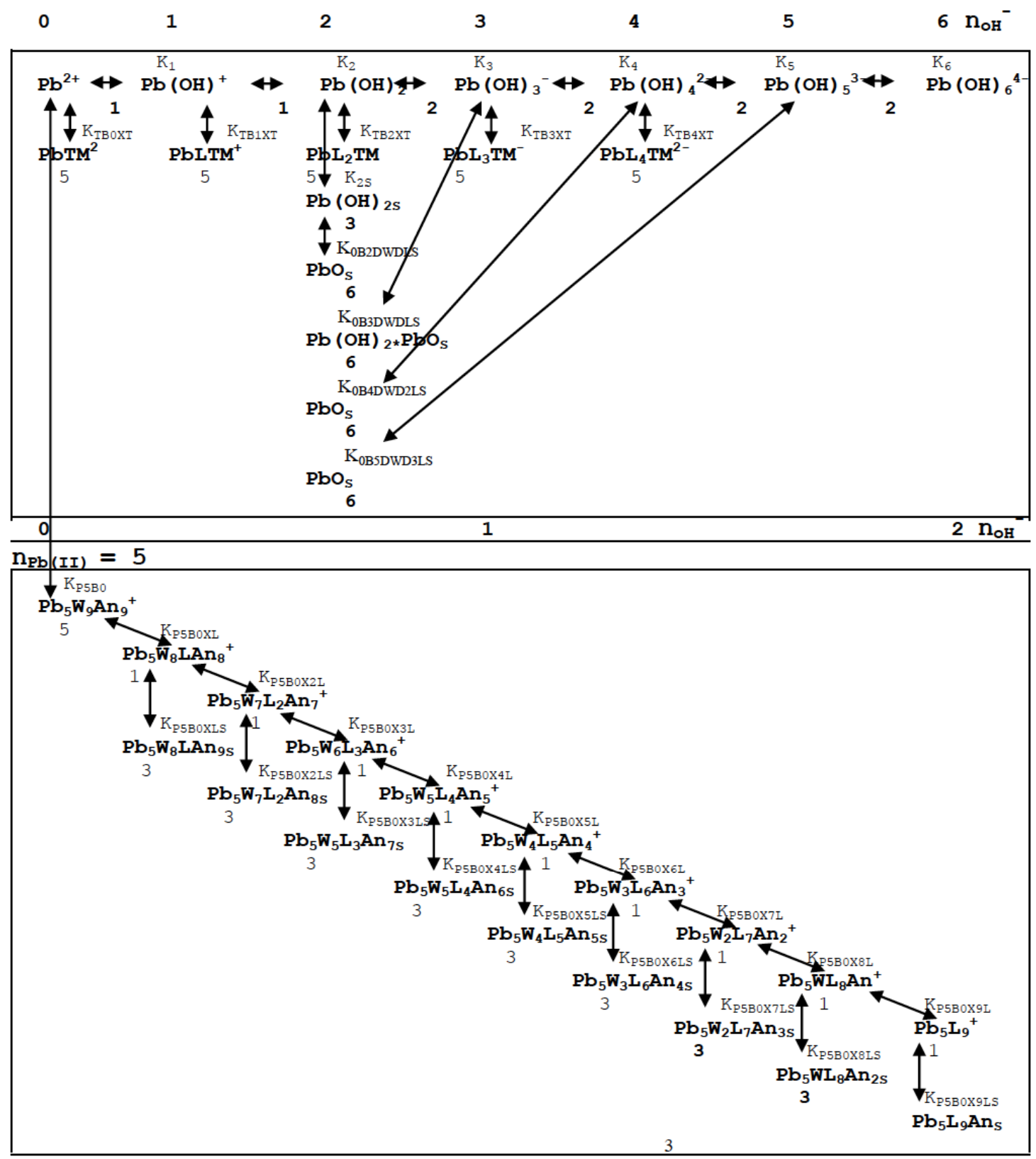

Figure 1: Scheme of the main equilibriums in the $\left[\mathrm{Pb}(\mathrm{II})-\mathrm{H}_{2} \mathrm{O}-\mathrm{OH}^{-}, \mathrm{TU}\right]$ system. $\mathrm{W}-\mathrm{H}_{2} \mathrm{O}, \mathrm{An}-\mathrm{NO}_{3}^{-}, \mathrm{L}_{-} \mathrm{OH}^{-}$. $\mathrm{Near}$ the sign $\leftrightarrow$ and over the symbol of compound is the index of the stability constant and at the bottom is the number of the reaction mechanism: 1. bonding of $\mathrm{H}_{2} \mathrm{O}$ and dissociation of $\mathrm{H}_{3} \mathrm{O}^{+}$; 2. bonding of $\mathrm{OH}^{-}$ion; 3. molecular precipitation; 4. precipitation of counterions in the core; 5. two-particle merging; 6. precipitation through intermediate decay. $\mathrm{n}_{\mathrm{OH}^{-}}-\mathrm{f}_{\mathrm{n}} \mathrm{ction}_{\mathrm{o}}$ of formation, with respect to the hydroxyl ion. $\mathrm{n}_{\mathrm{Pb}(\mathrm{II})}$ - function of formation, with respect to metal ions. The following $\mathrm{precipitates:} \mathrm{Pb}(\mathrm{OH})_{2(\mathrm{~S})}$, $\mathrm{Pb}(\mathrm{OH})_{2} \mathrm{PbO}_{(\mathrm{S})}, \mathrm{PbO}_{(\mathrm{S})}$ (green), $\mathrm{PbO}_{(\mathrm{S})}$ (litharge) are formed in the regions of existence in solution of $\mathrm{Pb}(\mathrm{OH})_{2}, \mathrm{~Pb}(\mathrm{OH})_{3}{ }^{-}$, $\mathrm{Pb}(\mathrm{OH})_{4}{ }^{2-}, \mathrm{Pb}(\mathrm{OH})_{5}{ }^{3-}$ respectively. 
Table 2: Calculated (in bold) and the Estimated Values of the Concentration Equilibrium Constants in the $\left[\mathrm{Pb}(\mathrm{II})-\mathrm{H}_{2} \mathrm{O}-\right.$ $\mathrm{OH}^{\prime}, \mathrm{TU}$ ] System, (PT - Potentiometric Titration, RC - Residual Concentration, TU - Thiourea)

\begin{tabular}{|c|c|c|c|c|c|c|c|c|c|c|c|c|}
\hline \multirow{3}{*}{$\begin{array}{c}\text { Parameters } \\
\mathrm{pC}_{\mathrm{Pb}(I I)}\end{array}$} & \multicolumn{9}{|c|}{ PT } & \multicolumn{3}{|c|}{ RC } \\
\hline & \multicolumn{10}{|c|}{25 oc } & \multirow{2}{*}{$\begin{array}{c}\mathbf{4 5}{ }^{\circ} \mathrm{C} \\
1.0\end{array}$} & \multirow{2}{*}{$\frac{65^{\circ} \mathrm{C}}{1.0}$} \\
\hline & 5.0 & 4.0 & 4.0 & 3.0 & 3.0 & 3.0 & 2.0 & 2.0 & 1.0 & 1.0 & & \\
\hline $\mathrm{pC}_{\mathrm{NaOH}}$ & 2.0 & 2.0 & 2.0 & 1.0 & 1.0 & 2.0 & 1.0 & 1.0 & 1.0 & 1.0 & 1.0 & 1.0 \\
\hline $\mathrm{pC}_{\mathrm{TU}}$ & 4.0 & 3.0 & 0 & 2.0 & 0 & 0 & 0 & 0 & 0 & 0 & 0 & 0 \\
\hline $\operatorname{lgK}_{1}$ & \multicolumn{12}{|c|}{$5.8 \pm 0.1\left(\mathrm{~K}_{1}=\left[\mathrm{Pb}(\mathrm{OH})^{+}\right] /\left[\left[\mathrm{Pb}^{2+}\right] \cdot[\mathrm{OH}]\right)\right.$} \\
\hline $\operatorname{lgK}_{2}$ & \multicolumn{12}{|c|}{$3.1 \pm 0.1\left(\mathrm{~K}_{2}=\left[\mathrm{Pb}(\mathrm{OH})_{2}\right] /\left[\mathrm{Pb}(\mathrm{OH})^{+}\right] \cdot[\mathrm{OH}]\right)$} \\
\hline $\operatorname{lgK}_{3}$ & \multicolumn{11}{|c|}{$\left.3.4 \pm 0.1\left(\mathrm{~K}_{3}=\left[\mathrm{Pb}(\mathrm{OH})_{3}\right]^{-}\right] /\left(\mathrm{Pb}(\mathrm{OH})_{2}\right] \cdot\left[\mathrm{OH}^{-}\right]\right)$} & 3.7 \\
\hline $\operatorname{lgK}_{4}$ & \multicolumn{12}{|c|}{$2.2 \pm 0.1\left(\mathrm{~K}_{4}=\left[\mathrm{Pb}(\mathrm{OH})_{4}{ }^{2}\right] /\left(\left[\mathrm{Pb}(\mathrm{OH})_{3}\right] \cdot\left[\mathrm{OH}^{2}\right]\right)\right.$} \\
\hline $\operatorname{lgK}_{5}$ & \multicolumn{12}{|c|}{$-1\left(\mathrm{~K}_{5}=\left[\mathrm{Pb}(\mathrm{OH})_{5}{ }^{3-}\right] /\left(\left[\mathrm{Pb}(\mathrm{OH})_{4}{ }^{2}\right] \cdot[\mathrm{OH}]\right)\right.$} \\
\hline $\operatorname{lgK}_{6}$ & \multicolumn{12}{|c|}{$-4\left(\mathrm{~K}_{6}=\left[\mathrm{Pb}(\mathrm{OH})_{6}{ }^{4}\right] /\left[\left(\mathrm{Pb}(\mathrm{OH})_{5}{ }^{2}\right] \cdot[\mathrm{OH}]\right)\right.$} \\
\hline $\operatorname{lgK}_{2 S}$ & \multicolumn{10}{|c|}{$-5.6 \pm 0.2\left(\mathrm{~K}_{2 \mathrm{~S}}=\left[\mathrm{Pb}(\mathrm{OH})_{2}\right]\right)$} & -4.9 & -4.5 \\
\hline $\lg K_{\text {Р } 50}$ & \multicolumn{12}{|c|}{$2.0\left(\mathrm{~K}_{\mathrm{P} 5 \mathrm{~B} 0}=\left[\mathrm{Pb}_{5}\left(\mathrm{H}_{2} \mathrm{O}\right)_{9}{ }^{10+}\right] /\left[\mathrm{Pb}^{2+}\right]^{5}\right)$} \\
\hline $\operatorname{lgK} K_{\text {PBBOS }}$ & \multicolumn{12}{|c|}{$-9.1\left(\mathrm{~K}_{\text {P5BOS }}=\left[\mathrm{Pb}_{5}\left(\mathrm{H}_{2} \mathrm{O}\right)_{9}{ }^{10+}\right] \cdot\left[\mathrm{NO}_{3}\right]^{-10}\right)$} \\
\hline $\lg K_{\text {Р5в0XL }}$ & \multicolumn{12}{|c|}{$7.1\left(\mathrm{~K}_{\text {P5BOXL }}=\left[\mathrm{Pb}_{5}\left(\mathrm{H}_{2} \mathrm{O}\right)_{8}(\mathrm{OH})^{9+}\right]\left[\mathrm{Pb}_{5}\left(\mathrm{H}_{2} \mathrm{O}\right)_{9}{ }^{10+}\right] /\left[\mathrm{OH}^{-}\right]\right)$} \\
\hline $\lg \mathrm{K}_{\mathrm{P} 5 \mathrm{BO} \mathrm{O} L \mathrm{~S}}$ & \multicolumn{12}{|c|}{$-13.3\left(\mathrm{~K}_{\text {P5BoxLS }}=\left[\mathrm{Pb}_{5}\left(\mathrm{H}_{2} \mathrm{O}\right)_{8}(\mathrm{OH})^{9+}\right] \cdot\left[\mathrm{NO}_{3}\right]^{9}\right)$} \\
\hline $\operatorname{lgK}_{\text {Р5BOX2L }}$ & \multicolumn{12}{|c|}{$15.7\left(\mathrm{~K}_{\text {Р } 5 \mathrm{BOX} 2 \mathrm{~L}}=\left[\mathrm{Pb}_{5}\left(\mathrm{H}_{2} \mathrm{O}\right)_{7}(\mathrm{OH})_{2}^{{ }^{8+}}\right]\left[\mathrm{Pb}_{5}\left(\mathrm{H}_{2} \mathrm{O}\right)_{8}(\mathrm{OH})^{9+}\right] /[\mathrm{OH}]\right)$} \\
\hline $\lg K_{\text {P5BOX2LS }}$ & \multicolumn{12}{|c|}{$\left.-12.8\left(\mathrm{~K}_{\text {P5BOX } 2 L \mathrm{~S}}=\left[\mathrm{Pb}_{5}\left(\mathrm{H}_{2} \mathrm{O}\right)_{7}(\mathrm{OH})_{2}^{8+}\right] \cdot\left[\mathrm{NO}_{3}\right]^{8}\right)^{8}\right)$} \\
\hline $\lg K_{\text {P } 5 \text { вох3L }}$ & 24.9( & BOXзL $=$ & ${ }_{5}\left(\mathrm{H}_{2} \mathrm{O}\right.$ & $\mathrm{DH})_{3}^{7+}$ & $\mathrm{b}_{5}\left(\mathrm{H}_{2} \mathrm{C}\right.$ & $(\mathrm{OH})_{2}$ & $\left.\left.\mathrm{OH}^{-}\right]\right)$ & & & & & \\
\hline IgK & -10.8 & 5BOXзLS & $\mathrm{b}_{5}\left(\mathrm{H}_{2}\right.$ & $(\mathrm{OH})_{3}$ & $\left.\mathrm{NO}_{3}\right]^{7}$ & & & & & & & \\
\hline $\lg K_{P 5 B 0 \times 4 L}$ & $34.2(\mathrm{~K}$ & $0 \times 4 L=[1$ & $\left(\mathrm{H}_{2} \mathrm{O}\right)_{5}$ & $\left.-1){ }_{4}^{6+}\right] /[$ & $\left(\mathrm{H}_{2} \mathrm{O}\right)$ & $\mathrm{HH})_{3}^{7+}$ & $\left.\left.\mathrm{H}^{\mathrm{H}}\right]\right)$ & & & & & \\
\hline $\lg K_{\text {P5BOX4LS }}$ & -11.1 & 5BOX4LS & $b_{5}\left(H_{2}\right.$ & $(\mathrm{OH})_{4}$ & $\left.\mathrm{NO}_{3}\right]^{6}$ & & & & & & -10.1 & -9.5 \\
\hline IgK & 42.6( & Box5L $=$ & ${ }_{5}\left(\mathrm{H}_{2} \mathrm{O}\right.$ & $\mathrm{OH})_{5}^{5+}$ & $b_{5}\left(\mathrm{H}_{2} \mathrm{C}\right.$ & $(\mathrm{OH})_{4}$ & $\left.\left.\mathrm{OH}^{-}\right]\right)$ & & & & & \\
\hline $\lg \mathrm{K}_{\text {P5BOX5LS }}$ & $-8.8(r$ & $30 \times 5 L S=$ & $b_{5}\left(\mathrm{H}_{2} \mathrm{C}\right.$ & $\mathrm{OH})_{5}^{5+}$ & $\left.\left.\mathrm{NO}_{3}\right]^{5}\right)$ & & & & & & & -8.3 \\
\hline $\lg \mathrm{K}_{\text {Р }}$ В0X6L & 48.8 & BOX6L $=$ & ${ }_{5}\left(\mathrm{H}_{2} \mathrm{O}\right.$ & $\mathrm{OH})_{6}^{4+}$ & $\mathrm{b}_{5}\left(\mathrm{H}_{2} \mathrm{C}\right.$ & $(\mathrm{OH})_{5}$ & $\left.\left.\mathrm{OH}^{-}\right]\right)$ & & & & & \\
\hline $\lg \mathrm{K}_{\text {Р5вох6LS }}$ & $-8.8(r$ & $0 \times 6 \mathrm{LLS}=$ & $\mathrm{b}_{5}\left(\mathrm{H}_{2} \mathrm{C}\right.$ & $\mathrm{OH})_{6}{ }^{4}$ & $\left.\left.\mathrm{NO}_{3}\right]^{4}\right)$ & & & & & & & \\
\hline $\lg K_{\text {Р }}$ B0х7L & 58.9 & ${ }_{B 0 \times 7 L}=$ & $\mathrm{O}_{5}\left(\mathrm{H}_{2} \mathrm{O}\right.$ & $\mathrm{OH})_{7}^{3+}$ & $\mathrm{b}_{5}\left(\mathrm{H}_{2} \mathrm{C}\right.$ & $(\mathrm{OH})_{6}$ & $\left.\left.\mathrm{OH}^{-}\right]\right)$ & & & & & \\
\hline $\operatorname{lgK}_{\text {P5BOX7LS }}$ & $-4.9(r$ & $0 \times 7 \mathrm{LS}=$ & $\mathrm{b}_{5}\left(\mathrm{H}_{2} \mathrm{C}\right.$ & $\mathrm{OH})_{7}^{3}$ & $\left.\left.\mathrm{NO}_{3}\right]^{3}\right)$ & & & & & & -4.6 & -4.6 \\
\hline $\lg K_{\text {Р } 5 \text { B0X8L }}$ & 63.81 & BOX8L=[ & $\left(\mathrm{H}_{2} \mathrm{O}\right)$ & H) $\left.{ }_{8}{ }^{2+}\right] /[$ & $\left(\mathrm{H}_{2} \mathrm{O}\right)$ & $\mathrm{H})_{7}^{3+}$ & $\mathrm{H}]$ ) & & & & 63 & 63 \\
\hline $\operatorname{lgK}_{\text {Р5BоX8LS }}$ & $-5\left(K_{P}\right.$ & $8 L S=[$ & $\left(\mathrm{H}_{2} \mathrm{O}\right)$ & -1) $\left.{ }_{8}^{2+}\right] \cdot[$ & & & & & & & -4.8 & -4.7 \\
\hline $\lg \mathrm{K}_{\mathrm{P} 5 \mathrm{~B} 0 \times 9 \mathrm{~L}}$ & 60.6( & ${ }_{B 0 \times 9 L}=$ & $\mathrm{O}_{5}(\mathrm{OH})$ & $\mathrm{Pb}_{5}(\mathrm{r}$ & $(\mathrm{OH})_{\varepsilon}$ & {$\left[\mathrm{OH}^{-}\right]$} & & & & & & \\
\hline $\lg \mathrm{K}_{\text {Р5вох9LS }}$ & -10.3 & 5BOX9LS & $\mathrm{Pb} 5(\mathrm{O}$ & $\left.{ }^{+}\right] \cdot[\mathrm{NO}$ & & & & & & & -7.5 & -7.2 \\
\hline $\lg \mathrm{K}_{\text {ов2DW }}$ & $-0.9(r$ & EDW $=1$ & $\left.(\mathrm{OH})_{2}\right]$ & $\mathrm{b}(\mathrm{OH})_{3}$ & & & & & & & & \\
\hline lgK & $-4.9(r$ & 2Dws [F & $\left.\mathrm{DH})_{2}\right] \cdot[$ & $(\mathrm{OH})_{3}$ & & & & & & & & \\
\hline $\mathrm{IgK}_{\text {овзош }}$ & $-3.0(r$ & ${ }_{B D W}=1$ & $\mathrm{O}(\mathrm{OH})$ & $\mathrm{Pb}(\mathrm{OH}$ & & & & & & & & \\
\hline IgK овзошs & $-6.4(r$ & $3 \mathrm{DWw}=$ & $(\mathrm{OH})_{3}$ & & & & & & & & -5.4 & -5.1 \\
\hline $\operatorname{lgK}_{\mathrm{OB} 4 \mathrm{DW}}$ & $-4.1(r$ & $4 \mathrm{DW}=1$ & $\mathrm{O}(\mathrm{OH})$ & $/ \mathrm{Pb}(\mathrm{O}$ & & & & & & & & \\
\hline IgK & $-5.2(r$ & 4DWs = & $(\mathrm{OH})_{4}$ & & & & & & & & & \\
\hline lgK $\mathrm{K}_{\mathrm{OB} 5 \mathrm{DW}}$ & $-7.0(r$ & EDW $=1$ & $\mathrm{O}(\mathrm{OH})$ & {$[\mathrm{Pb}(\mathrm{O}$} & & & & & & & & \\
\hline $\lg \mathrm{K}_{\mathrm{OB} 5 \mathrm{DWs}}$ & $-8.3(r$ & SDWs = & $(\mathrm{OH})_{5}$ & & & & & & & & & \\
\hline $\lg _{T H}$ & $-10(\mathrm{~K}$ & $=\left[\mathrm{TH}^{+}\right.$ & ]$\left.\left[\mathrm{H}^{+}\right]\right)$ & & & & & & & & - & - \\
\hline $\operatorname{lgK}_{T}$ & $-2\left(\mathrm{~K}_{\mathrm{T}}\right.$ & $\mathrm{T}] /[\mathrm{T}]$ & & & & & & & & & - & - \\
\hline $\operatorname{lgK}_{\text {твохт }}$ & $4\left(\mathrm{~K}_{\mathrm{TB}}\right.$ & $=[\mathrm{Pb}]$ & {$\left[\mathrm{Pb}^{2+}\right]$} & & & & & & & & - & - \\
\hline $\lg K_{\text {TB1XT }}$ & $3.2(\mathrm{~K}$ & $\mathrm{KT}_{\mathrm{T}}=[\mathrm{P}$ & $\left.\mathrm{H}) \mathrm{T}^{+}\right]$ & $\mathrm{O}(\mathrm{OH})$ & & & & & & & - & - \\
\hline $\operatorname{lgK} \mathrm{K}_{\mathrm{TB2} X \mathrm{~T}}$ & $6.6(\mathrm{~K}$ & $\mathrm{KT}_{\mathrm{T}}=[\mathrm{P}$ & $\left.\mathrm{H})_{2} \mathrm{~T}\right]$ & $\mathrm{O}(\mathrm{OH})_{2}$ & & & & & & & - & - \\
\hline $\lg K_{\text {TB3Xт }}$ & $4\left(\mathrm{~K}_{\mathrm{TB}}\right.$ & $=[\mathrm{Pb}$ & 1) $\left.{ }_{3} \mathrm{~T}\right] /[\mathrm{P}$ & $\left.(\mathrm{OH})_{3}\right]$ & & & & & & & - & - \\
\hline $\lg K_{\text {TB4XT }}$ & $3\left(\mathrm{~K}_{\mathrm{TB}}\right.$ & $=[\mathrm{Pb}$ & $\left.\mid)_{4} T^{2}\right] / \mid$ & $(\mathrm{OH})_{4}^{2}$ & & & & & & & - & - \\
\hline IgK & $-5\left(K_{P}\right.$ & $8 L \mathrm{BT}=[\mathrm{P}$ & $\left.\mathrm{H}_{2} \mathrm{O}\right)($ & )$_{8} \mathrm{~T}_{2}^{+} \mathrm{J} / \mathrm{C}$ & ${ }_{5}\left(\mathrm{H}_{2} \mathrm{O}\right.$ & $\mathrm{H})_{8}{ }^{2+}$ & & & & & - & - \\
\hline
\end{tabular}


Table 3: The Algorithm for Modeling the Region of Precipitation in the $\left[\mathrm{Pb}(\mathrm{II})-\mathrm{H}_{2} \mathrm{O}-\mathrm{OH}^{-}\right.$, TU] System, with Respect to the $\mathrm{pH}$ of Solution and Concentration of Reagents. Expressions for the Equilibrium Constants are Presented in Table 2

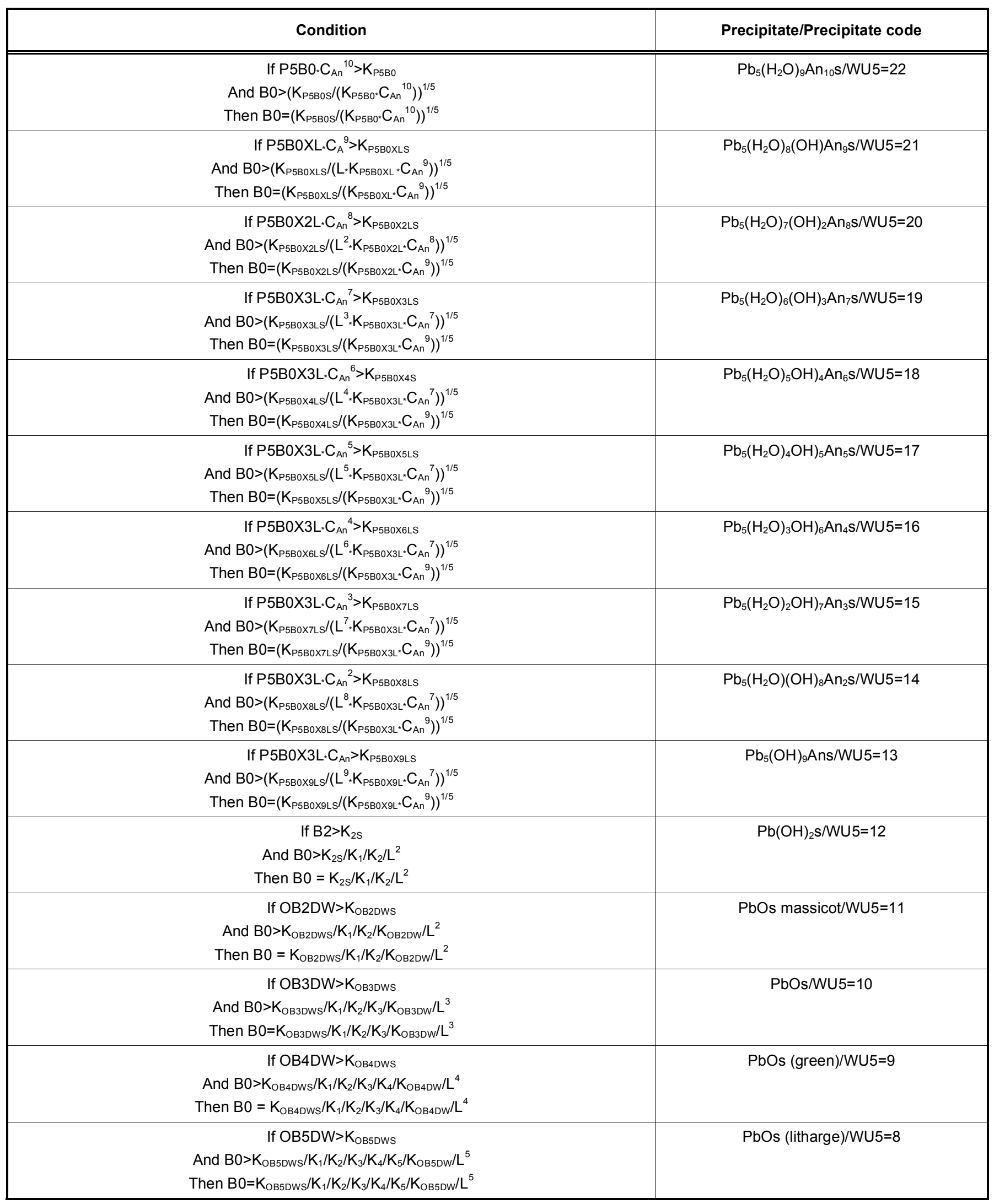


theoretical curves of potentiometric titration (PT) or residual concentration (RC) is required. For this, it is necessary to use, not only the above four conditions of solution saturation, but also a definite sequence of their application. For example, if computations begin with low $\mathrm{pH}$ values, the region of existence of the first precipitate is modeled by using one of the three conditions of solution saturation, but the regions of existence of subsequent precipitates are modeled, adding the condition of the precipitate of priority. Table 3 below shows the algorithm for modeling the region of precipitation in the $\left[\mathrm{Pb}(\mathrm{II})-\mathrm{H}_{2} \mathrm{O}-\mathrm{OH}^{-}\right.$, TU] system, with respect to $\mathrm{pH}$ and concentration of reactants.

In the top rectangle of Figure 1, five precipitates have been presented: $\mathrm{Pb}(\mathrm{OH})_{2(\mathrm{~S})}$ (white hydroxide precipitate), $\mathrm{PbO}_{(\mathrm{S})}$ (yellow oxide precipitate; massicot), $\mathrm{Pb}(\mathrm{OH})_{2} \star \mathrm{PbO}_{(\mathrm{S})}$ (white oxyhydroxide precipitate), $\mathrm{PbO}_{(\mathrm{S})}$ (green oxide precipitate), $\mathrm{PbO}_{(\mathrm{S})}$ (red oxide precipitate; litharge). The function of formation by hydroxyl ion of these precipitates equals two, and if the rule of the solubility product only is used, their region of formation should overlap with that of $\mathrm{Pb}(\mathrm{OH})_{2(\mathrm{~S})}$, but only one of these precipitates should be formed, with respect to the solubility constant value. In fact, this is right for the hydroxide precipitate, whose region of formation overlaps with the region of existence of the $\mathrm{Pb}(\mathrm{OH})_{2}$ complex in solution, in significant molar fractions, as well as, for massicot, which is formed by dehydration of $\mathrm{Pb}(\mathrm{OH})_{2}$ through exposure of the system to X-ray, and in certain other conditions. The regions of formation of other precipitates overlap with the regions of existence of other lead hydroxycomplexes (intermediates): $\mathrm{Pb}(\mathrm{OH})_{2} \times \mathrm{PbO}_{(\mathrm{S})}$ with $\mathrm{Pb}(\mathrm{OH})_{3}{ }^{-}, \mathrm{PbO}_{(\mathrm{S})}$ (green) with $\mathrm{Pb}(\mathrm{OH})_{4}{ }^{-2}, \mathrm{PbO}_{(\mathrm{S})}$ (litharge) with $\mathrm{Pb}(\mathrm{OH})_{5}{ }^{-3}$. Sequential formation of these precipitates can be described theoretically, using only the condition of intermediary saturation of solution [2].

In the next rectangle of Figure 1, where $n_{\mathrm{Pb}(\mathrm{II})}=5$, there are a number of polynuclear compounds both in solution and in the form of precipitates, with identical structures but with different water content or hydroxyl ion - $\mathrm{Pb} 5\left(\mathrm{H}_{2} \mathrm{O}\right)_{9-x}(\mathrm{OH})_{x} \mathrm{An}_{10-x}$, where $\mathrm{x}=0 \div 10$. It is also possible that this series is composed of $\mathrm{Pb} 10\left(\mathrm{H}_{2} \mathrm{O}\right)_{20-x}(\mathrm{OH})_{x} A n_{20-x}$, where $\mathrm{x}=0 \div 20$; it is necessary to establish this in the course of further research. The possible structure of the first series of polynuclear compounds is trigonal bipyramidal (coordination number of the lead atom is three); and for the second series, the possible structure is a cube with two atoms of lead on two opposite sides with coordination number of the lead atom being four. All regions of precipitations of a given series of polynuclear compounds are modeled using the rule of solubility product and the rule of selection of the precipitate of priority. Experimental and estimated (computational) regions of formation of the given precipitates have been presented in Figures $\mathbf{1}$ and $\mathbf{3}$. This series of compounds determines the emergence of $\mathrm{pH}$ fluctuations of the solution.

The compounds presented in Figure 1 have significant mole fractions, and are an integral part of the material balance equation of the $\left[\mathrm{Pb}(\mathrm{II})-\mathrm{H}_{2} \mathrm{O}-\mathrm{OH}^{-}\right.$, TU] system. For the reduction of the dimension of tasks

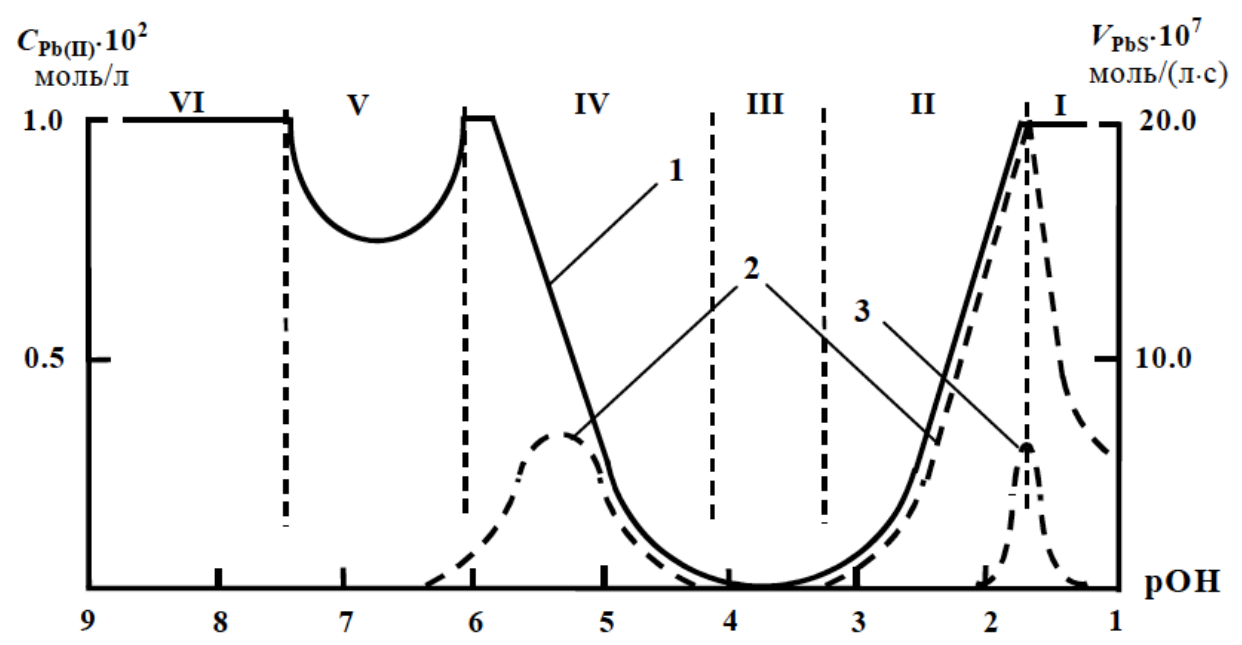

Figure 2: Dependencies on $\mathrm{pOH}: 1$ - residual concentration of $\mathrm{Pb}(\mathrm{II}) ; 2$ - rate of precipitation of $\mathrm{PbS}$; and 3 - rate of formation of $\mathrm{PbS}$ in the form of a thin film. Regions of Precipitation: I - complete absence of precipitation at high concentrations of $\mathrm{OH}^{-}$ and low concentrations of $\mathrm{Pb}(\mathrm{II})$; II - dissolution of precipitates of neutral hydroxocomplexes and oxides; III - most complete, and IV - partial precipitation of the neutral complex; V - precipitation of polynuclear compounds; VI - complete absence of precipitation at high $\mathrm{pOH}$ values. 



Figure 3: Dependence of thickness of $\mathrm{PbS}$ thin film and potassium concentration in the thin film, on the $\mathrm{pH}$ of solution. $\mathrm{t}=25^{\circ} \mathrm{C}$, $C_{\mathrm{Pb}(\mathrm{II})}=0.0080 \mathrm{~mol} / \mathrm{l}, C_{\mathrm{TM}}=0.0120 \mathrm{~mol} / \mathrm{l}$. Data was taken from [8].

in the calculation of the equilibrium constants listed in Table 2, the system's $\mathrm{pH}$ was divided into six regions along the coordinate (see Figure 2). Regions I and VI correspond to the condition of the absence of precipitates, respectively, at high and low $\mathrm{pH}$ values of the solution. Region $\mathrm{V}$ corresponds to precipitates of polynuclear compounds, IV - precipitates of neutral hydroxide or metal oxide, III — precipitate of oxyhydroxide, II - precipitate of metal oxides, depositing sequentially one after the other.

By introducing TU into the $\left[\mathrm{Pb}(\mathrm{II})-\mathrm{H}_{2} \mathrm{O}-\mathrm{OH}^{-}\right]$ system, lead sulfide is formed, the rate of formation of which (curve 2), as shown in Figure 3, corresponds to the above-mentioned regions. The compounds in solution participate in the reaction of formation of the

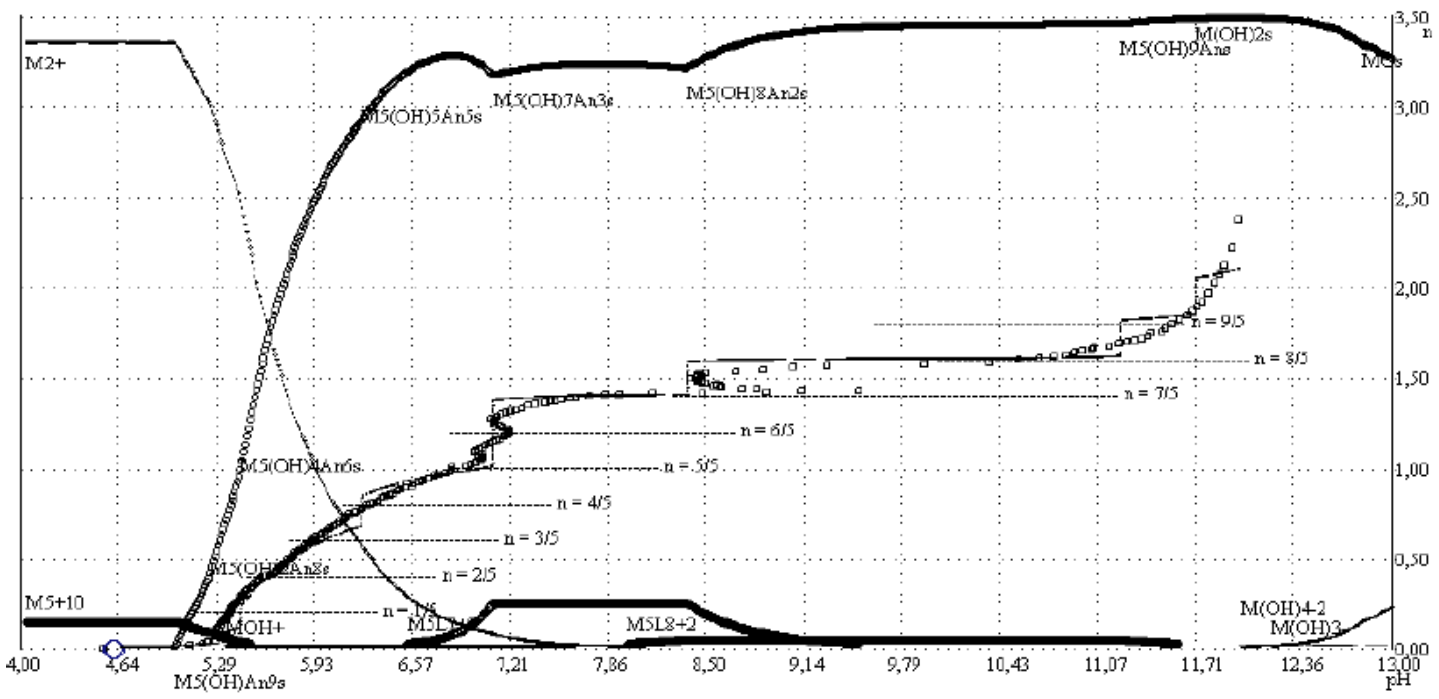

Figure 4: Experimental titration curve at $25.0{ }^{\circ} \mathrm{C}$ of $0.100 \mathrm{~mol} / \mathrm{l} \mathrm{Pb}\left(\mathrm{NO}_{3}\right)_{2}$ solution with $0.100 \mathrm{~mol} / \mathrm{l} \mathrm{NaOH}$ solution (squares). In

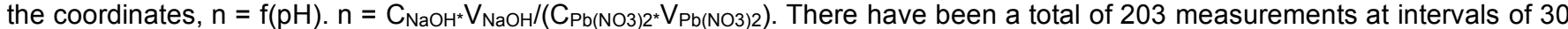
seconds after addition of the titrant and intensive mixing. The estimated titration curve is displayed in dotted lines. Calculated molar fractions of compounds are represented as circles. Hydroxocomplexes that are in solution are represented by tiny circles. Polynuclear compounds are represented by much larger circles. The composition of compounds is shown at the beginning of their formation on the $\mathrm{pH}$ scale. Compounds in the form of precipitates are represented with the index " $\mathrm{s}$ ". $\mathrm{M}-\mathrm{Pb}(\mathrm{II}), \mathrm{An}^{-\mathrm{NO}}{ }_{3}^{-}$. Mole fraction of 1 corresponds to $n=3.50$. The calculated value of $\mathrm{pH}$ due to the hydrolysis of $0.100 \mathrm{~mol} / \mathrm{l} \mathrm{Pb}(\mathrm{NO} 3)_{2}$ solution, considering all compounds present in the system, is represented with a large circle. 


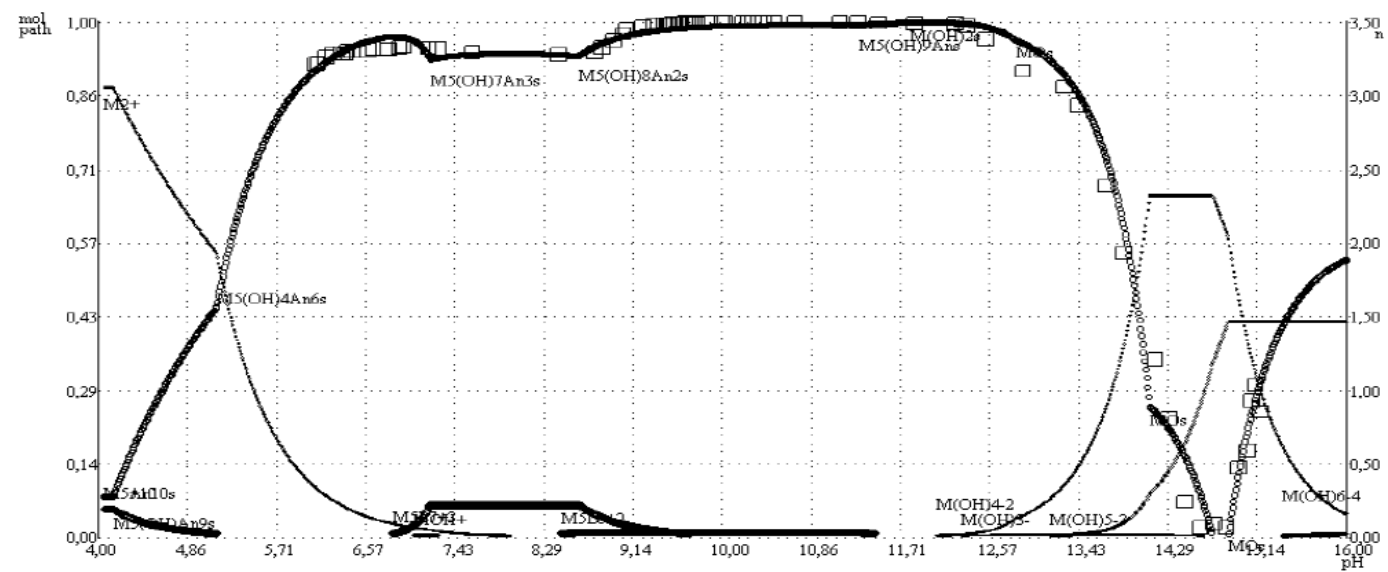

(a)

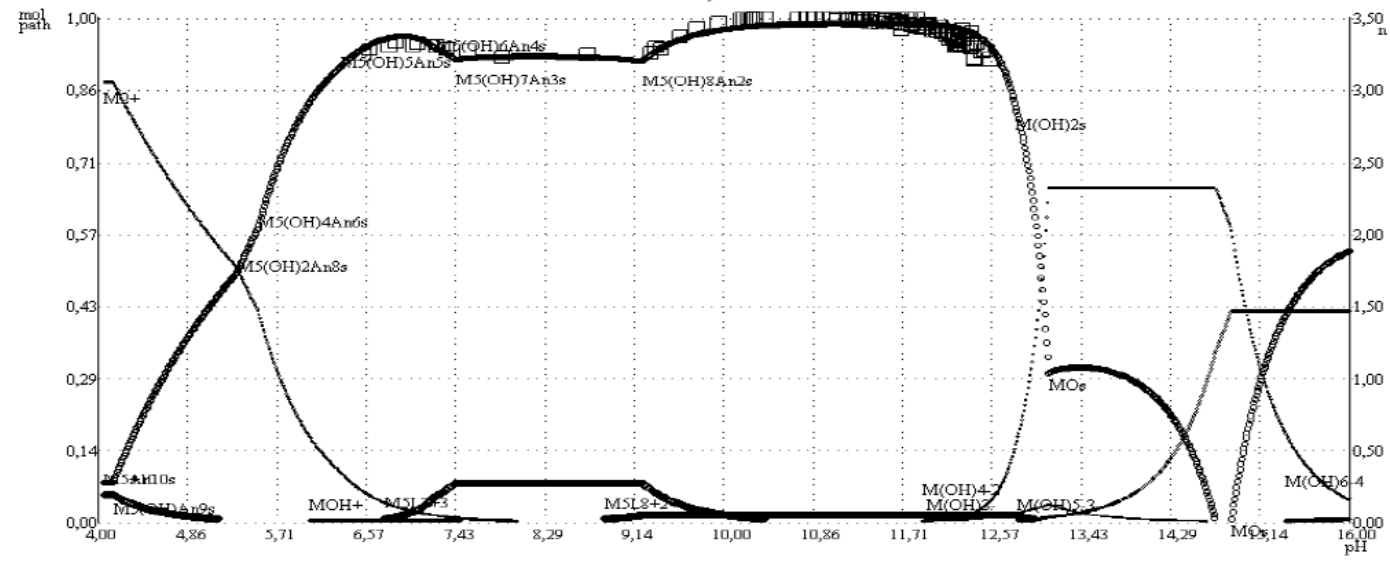

(b)

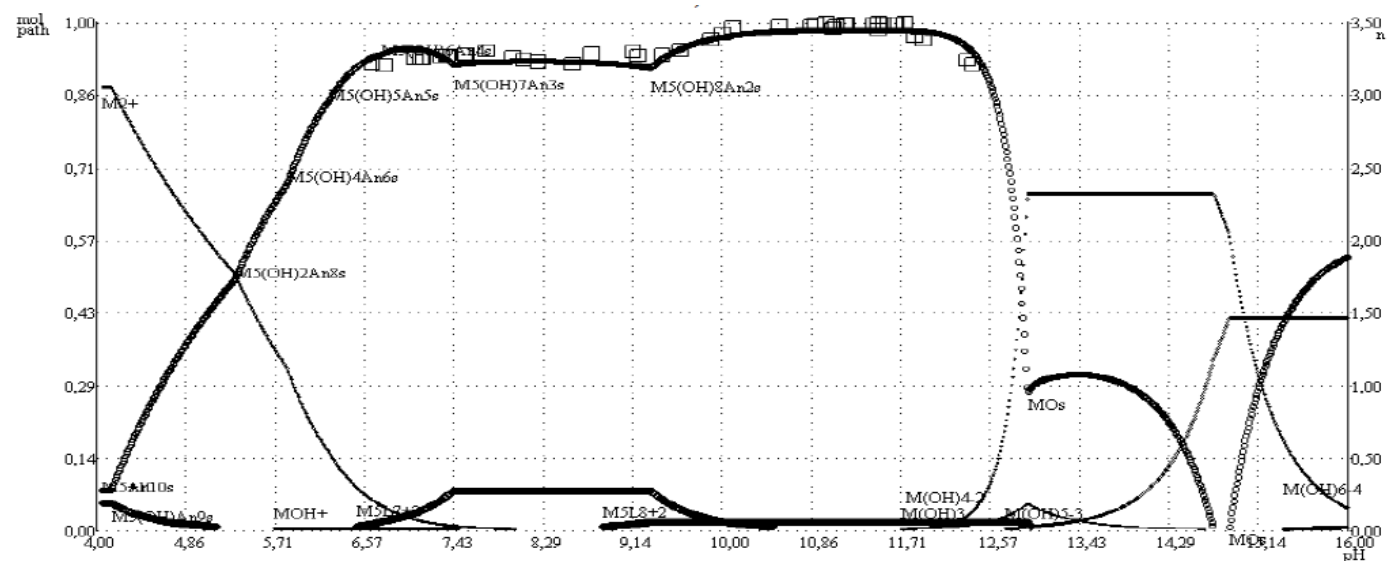

(c)

Figure 5: The experimental curves of residual concentration (RC) at (a) 25.0, (b) $45.0,(\mathbf{c}) 65.0{ }^{\circ} \mathrm{C} \mathrm{of} 0.130 \mathrm{~mol} / \mathrm{l} \mathrm{Pb}(\mathrm{NO})_{2}$ solution (squares). Hold-up time of solutions is 2 weeks (experimental data is taken from [8]. Estimated residual concentration (RC) titration curve is displayed with circles, using the values of the constants presented in Table 2. Estimated molar fractions of compounds are represented in the form of circles. Hydroxocomplexes that are in solution are represented by tiny circles. Polynuclear compounds are represented by much larger circles. The compositions of compounds are shown at the beginning of their formation on the $\mathrm{pH}$ scale. Compounds in the form of precipitates are represented with the index " $\mathrm{s}$ ". $\mathrm{M}-\mathrm{Pb}(\mathrm{II}), \mathrm{An}-\mathrm{NO}{ }_{3}{ }^{-}$.

sulfide, and the precipitates are inert, so the residual concentration of the metal ion in the system (curve 1) corresponds well with curve 2 . The region of formation of thin films of lead sulfide (curve 3 ) is also determined by regions of existence of $\mathrm{Pb}(\mathrm{OH})_{2}, \quad \mathrm{~Pb}(\mathrm{OH})_{3}{ }^{-}$, $\mathrm{Pb}(\mathrm{OH})_{2} \mathrm{TU}$ hydroxycomplexes, as well as, the surface area of lead sulfide as a catalyst. Figure $\mathbf{3}$ also illustrates how the thickness of the lead sulfide film 
formed, the concentration of impurities of potassium ions in the film and the regions of existence of compounds in the system depend on the $\mathrm{pH}$ of the solution.

Thus, in creating a mathematical model of a system and developing a software product, designed for the optimization of the conditions of synthesis, calculation or analysis of equilibrium constants, rate constants of precipitation reactions and formation of thin films of lead sulfide, the fastest and most economical method of obtaining experimental data is the method of potentiometric titration (PT). To account for the memory effect of the solution determined by the slowly-forming compounds in the system, it is necessary to use the method of residual concentration (RC), although this method is slow. By the PT and RC methods, we have shown that there is no memory effect factor of solution in the $\left[\mathrm{Pb}(\mathrm{II})-\mathrm{H}_{2} \mathrm{O}-\mathrm{OH}^{-}\right.$, TU] system, since by using one set of equilibrium constants shown in Table 2 , it is possible at a satisfactory level, to theoretically describe the experimental curves of both $\mathrm{PT}$ and RC, with regards to precipitations indicated in Figures $\mathbf{4}$ and $\mathbf{5}$. Experimental curves of PT and RC also provide meaningful information about the composition of compounds present in solution; and there are just a few research methods that would provide such data. Compositional and structural analyses of compounds released in the form of precipitates or thin films get easier with the software package developed by us.

\section{ACKNOWLEDGEMENTS}

The work was performed as part of the approved job № 4.1584.2014 / For competitive state of the job to 2014-2016 years.

\section{REFERENCES}

[1] Yusupov RA, Bakhteev SA. Calculation of the Regions of Solid Phase Precipitations in the Metal Ion-WaterComplexing Agent Systems. Russ J Phys Chem A 2009; 83(12): 2188-2190. http://dx.doi.org/10.1134/S0036024409120346

[2] Yusupov RA, Bakhteev SA, Smerdova SG. Calculation of Sediment Existence Regions in Metal Ion- $\mathrm{H}_{2} \mathrm{O}-\mathrm{Complex}$ Forming Agent Systems Taking Intermediate Solubilities into Account. Russ J Phys Chem A 2010; 84(7): 1263-1265. http://dx.doi.org/10.1134/S0036024410070320

[3] Yusupov RA, Mikhailov OV. Correlation between the stability Constants and solubility Constants of Metal Hydroxides. Russ J Inorg Chem 2002; 47(7): 1067-1069.

[4] Beresnev EN. The method of residual concentrationsMoscow: Nauka, 1992; [rus.]

[5] Bek M. The study of complexation latest techniques: (Translated from English). Moscow: Mir. 1989; p. 413 p. [rus.]

[6] Lurie YY. Handbook of Analytical Chemistry. Lurie YY., 6th ed., Rev. - M.: Chimiya. 1989; p. 480.

[7] Lidin RA. Constants of Inorganic Substances: A Handbook. Lidin RA, Andreeva LL, Molochko VA, ed. R.A. Lidin. - 2nd ed., Revised. and add. - M. Drofa, 2006; p. 685. 